\title{
DUISTERE BLADZIJDEN UIT DE GESCHIEDENIS VAN SURINAME
}

DOOR

\author{
C. K. KESLER
}

Hoewel over het geheel genomen, de geschiedenis onzer West-Indische koloniën slechts zelden opwekkend mag genoemd worden, moeten toch de bladzijden, waarop vermeld staat, wat er in de eerste jaren na de occupatie door de Zeeuwen geschied is, als bijzonder duister gesignaleerd worden. Duister in tweeërlei opzicht: vooreerst, daar door allerlei onderling gekrakeel de opbloei der kolonie, die onder Willoughby's beheer inderdaad wel wat beloofde, voor jaren achteruit gezet werd, maar ook, omdat het eenigszins bezwaarlijk is, zich een heldere voorstelling te vormen van al de stroomingen en tegenstroomingen, die in de eerste jaren de nieuwe Zeeuwsche kolonie in rep en roer brachten.

Zooals voldoende bekend is, had de royalistische edelman, Francis, 5th Baron of Parham, in 1651 de fondamenten gelegd voor de latere kolonie Suriname. Hoewel hij Gouverneur van Barbados was, stelde hij bijzonder belang in deze particuliere kolonisatie, waaraan hij in 10 jaar (1650-1661) £ 20.000 ten koste legde. En, in enkele opzichten tot schade voor Barbados, bevorderde hij zooveel mogelijk emigratie van planters van daar naar het nieuwe gebied, dat aan hem en aan Lawrence Hyde na de restauratie der Stuarts in 1663 in vollen eigendom ten eeuwigen dage werd afgestaan. Dat gebied omvatte, volgens den giftbrief, gedateerd 2 Juni 1663, het gebied tusschen de Coppename en de Marowijne met uitzondering van 
30.000 acres, die voor de Kroon gereserveerd werden ${ }^{1}$ ).

Zooals verder bekend is, kwam Lord Willoughby op 23 Juli 1666, toen hij met het fregat „The Hope” op weg was, om St. Kitts te ontzetten, in een orkaan om. Hij beleefde dus niet het verlies van zijn kolonie Willoughby's Land, die op het eind van Februari van het volgende jaar door den Gouverneur William Byam aan Abraham Krijnssen moest worden overgegeven.

Had Willoughby een voorgevoel gehad van zijn naderend einde? Men zou geneigd zijn, het te veronderstellen, als men overweegt, dat hij kort van te voren zijn testament gemaakt had, waarbij hij omtrent Willoughby's Land bepaalde, dat hij $2 / 3$ van zijn land en $2 / 3$ van de machinerieën op zijn plantage Parham's Hill vermaakte aan zijn beide dochters gezamenlijk en het resteerende gedeelte aan zijn neef Henry, den zoon van zijn broeder William, die hem, als 6th Baron of Willoughby en als Gouverneur van Barbados opvolgde. Dat testament heeft voor Suriname tot heel wat ellende aanleiding gegeven.

De 2e Engelsche oorlog was, wat de West betreft, eenigszins het kritieke tijdperk, waarin beslist zou worden, of het Engeland zou gelukken, onze Republiek vandaar te verdrijven. Aan pogingen daartoe had het in de afgeloopen jaren niet ontbroken. Maar het is niet gelukt; noch toen, noch ook in den volgenden oorlog, toen Frankrijk ertoe medehielp. Het leek een schaakspel; hier verloor de eene partij een stuk, daar nam zij er aan ander voor in de plaats. Nieuw-Nederland bleef voor ons verloren, maar Suriname kregen wij ervoor in de plaats.

Het leek er echter niet op, dat Engeland van zins was, den nieuwen toestand onvoorwaardelijk te aanvaarden. Integendeel, jaren lang is er gewerkt, eerst, korten tijd, om Suriname weer in bezit te krijgen, en, toen het duidelijk werd, dat daarop weinig kans bestond, werd de Britsche tactiek erop gericht, den vooruitgang ervan zooveel mogelijk te remmen en te trachten, ten koste van Suri-

\footnotetext{
1) Zie voor verdere bijzonderheden omtrent Willoughby o.a. Encyclopaedie voor West-Indië, blz. 749 en West-Indische Gids, jaargang 1926, afl. $1-2$.
} 
name, den bloei van Jamaica zooveel mogelijk te bevorderen.

Een poging, om Suriname weer in bezit te krijgen, gelukte aanvankelijk. St.-Kitts was tijdens den oorlog in handen der Franschen gevallen en het was op weg daarheen, dat Lord Willoughby in een orkaan omkwam. In het volgende jaar overwoog men van Britsche zijde een nieuwe poging, om het te hernemen. Daartoe werd in Juli 1667 op de reede van Nevis krijgsraad gehouden aan boord van het schip van Sir John Harman ${ }^{1}$ ), die in hetzelfde jaar tot admiraal en opperbevelhebber van de Britsche marine in de West-Indische wateren benoemd was. $\mathrm{Na}$ verschillende krijgsbedrijven tastte hij, toen in den krijgsraad uitgemaakt was, dat een nieuwe aanslag op St.-Kitts onraadzaam was, nog onbekend met het sluiten van den vrede van Breda, Suriname aan, dat op 6 October door Maurits de Rama moest worden overgegeven.

Op Byam's verzoek werd in een krijgsraad zijn beleid bij de overgave aan Krijnssen, zeven maanden te voren, beoordeeld en werd vastgesteld, dat dit, de omstandigheden in aanmerking genomen, geheel correct geweest was ${ }^{2}$ ).

Op de vloot van Sir John Harman was aanwezig de Luitenant-Generaal Henry Willoughby, die door zijn oom, Lord Francis tot erfgenaam van $1 / 3$ van diens bezittingen in Suriname benoemd was. Sir John Harman had soldaten en officieren op Nevis aangeworven en overeenkomstig het met deze gesloten contract, werden de thans weder in Britsche handen overgegane plantages hun toege-

1) Sir John Harman nam als kapitein o.a. deel aan den driedaagschen zeeslag bij Portland onder bevel van Blake. In den Tweeden Engelschen oorlog, toen hij inmiddels tot Schout-bij-Nacht bevorderd was, werd hij in den vierdaagschen zeeslag bij North-Foreland zwaar gewond door een vallenden ra. Na zijn herstel werd hij naar de West gezonden, waar hij, na een vergeefsche poging om St. Kitts te heroveren, de Fransche vloot bij Martinique versloeg, daarna 15 September Cayenne in bezit nam en 7 October 1667 voor Suriname aankwam. Na de herovering daarvan vertrok hij met zijn vloot naar Barbados en vandaar naar Engeland. Hij stierf 11 October 1673.

2) William Byam verliet kort daarop met eenige der eerste emigranten Suriname en begaf zich naar Antigua, waar hij, tot Gouverneur benoemd, in 1670 stierf. Twee zijner zwagers en zijn schoonzoon, Kolonel George Nedham, gehuwd met Mary Byam, waren voorname planters op Jamaica. 
wezen, als belooning voor de bij de expeditie bewezen diensten. Officieren en soldaten boden daarop de particuliere plantage der Willoughby's, Parham-Hill als zijn aandeel in den buit aan Henry Willoughby aan. Toen Harman's vloot vertrok, werden 100 man der troepen achtergelaten en Kolonel Samuel Barry ${ }^{1}$ ) tot Gouverneur benoemd.

Inmiddels was het bericht van het sluiten van den vrede van Breda op Barbados aangekomen en waren de voorwaarden daar bekend geworden. Dat die niet naar den zin der Willoughby's waren, is niet te verwonderen. Lord William Willoughby zond dan ook zijn zoon naar Suriname terug met opdracht, zooveel mogelijk van de inwoners met hun bezittingen weg te voeren en naar Antigua over te brengen. Mochten zij niet tot vertrekken gezind blijken, dan moest hij althans de kolonie in bezit houden, tot hij nadere bevelen van de Lords of Trade and Plantations ${ }^{2}$ ) ontvangen had. Zooals bekend is, voerde Henry Willoughby met een ijver, een betere zaak waardig, zijn opdracht uit. Een paar maanden lang deed hij zijn uiterste best, zooveel mogelijk van de plantages en fabrieken te verwoesten en roerende goederen weg te zenden. Bovendien trachtte hij de planters over te halen, hetzij naar Antigua, hetzij naar Barbados te emigreeren. Niet allen waren daartoe echter geneigd.

$\left.{ }^{1}\right)$ Samuel Barry was in 1655 in het leger van Venables naar Jamaica gekomen. Zes jaar later komt hij daar voor als 1ste Lid van den Raad en als Opperrechter. Hij was een der voornaamste landeigenaars en keerde waarschijnlijk, nadat hij van 3 Nov. 1667 tot 1 Febr. 1668 Gouverneur van Suriname geweest was, naar Jamaica terug, waar hij vermoedelijk omstreeks 1698 overleed. Zijn naam leeft nog voort in Barrystreet te Kingston.

$\left.{ }^{2}\right)$ Tijdens het bewind van Cromwell werd in Engeland opgericht een "Committee of Privy Council for Trade". De bedoeling hiervan was, een permanent lichaam te hebben, dat het Parlement in handelszaken zou kunnen voorlichten. Na de restauratie werd Cromwell's politiek te dien aanzien voortgezet. In 1660 werd een Commissie van den Privy Council ingesteld, om inlichtingen in te winnen omtrent in- en uitvoer en maatregelen voor te stellen in het belang van den handel. Enkele jaren later werd daarbij een nieuwe commissie gevoegd, om op te treden, als schakel tusschen de Kroon en de koloniën (foreign plantations, zooals zij destijds genoemd werden). Deze „Commission of Trade and Plantations" werd in 1675 opgeheven. Eerst 20 jaar later werd zij door Willem III opnieuw ingesteld. Van 1696-1700 was John Locke secretaris der commissie. 
Het regime van de Willoughby's was niet bij allen in den smaak gevallen. In 1665 was in de raadzaal te Thorarica door zekeren John Allen een aanslag op het leven van Lord Francis gedaan ${ }^{1}$ ). Kolonel Robert Sanford had zich in 1662 per rekest bij den Koninklijken Raad van Karel II over Byam beklaagd en de Raad der kolonie wendde zich tot den Lord-Proprietor met 19 klachten en onder bedreiging, dat de meeste ingezetenen de kolonie zouden verlaten, indien deze niet uit den weg geruimd werden.

Ook Henry Willoughby vond tegenstand. Dezelfde Robert Sanford, die in 1662 klachten over Byam had ingediend, beklaagde zich er in 1667 over, dat hij oplast van Lord William gevangen genomen en naar Engeland gezonden was, terwijl in hetzelfde jaar de Koninklijke Raad een rekest van zekeren Nathaniël Kingsland, destijds planter op Barbados, te behandelen kreeg, waarin deze zich er over beklaagde, dat Henry Willoughby zijn land in Suriname en zijn huis in de stad had verkocht en dat hij, na daartegen geprotesteerd te hebben, eveneens was gevangen genomen en naar Engeland gezonden ${ }^{2}$ ).

Zonder moeilijkheden van de zijde der Engelsche ingezetenen der kolonie ging dus het herstel van het Britsche gezag niet. En het was duidelijk, dat ook de Staten van Zeeland zich er niet bij zouden neerleggen. In Januari 1668 protesteerden de Staten-Generaal bij het Britsche hof wegens de wederrechterlijke inbezitneming van Suriname na het sluiten van den vrede en eischten, dat dit wederom zou worden teruggegeven ${ }^{3}$ ).

\footnotetext{
1) John Allen werd ter dood veroordeeld, maar pleegde voor zijn executie zelfmoord, en zijn goederen werden verbeurd verklaard. Door Willoughby was bepaald, dat zij aan de kerk zouden ten deel vallen. (Enc. West-Indië, blz. 185 en 434).

2) F. Cundall, The Migration from Surinam to Jamaica. („Timehri: The Journal of the Royal Agricultural and Commercial Society of British Guiana". Vol. VI. Third Series, September 1919.

s) Dit had ten gevolge, dat Lord Willoughby uit Engeland bevel ontving, ervoor zorg te dragen, dat het fort in Suriname overgegeven zou worden aan wie het bevel daartoe van wege den Koning toonde. Een gelijke opdracht werd verzonden aan den door Henry Willoughby aangestelden Gouverneur.

Vincent T. Harlow („A History of Barbados 1625-1685”, Oxford 1926, blz. 187) vermeldt daaromtrent het volgende:
} 
Inmiddels hadden de Staten van Zeeland reeds in Januari Abraham Krijnssen voor de tweede maal, thans met drie schepen naar de kolonie gezonden. Krijnssen kwam 25 April voor de Suriname-rivier en 1 Mei was de kolonie weer in ons bezit. James Banister, die haar sedert $1 \mathrm{Fe}-$ bruari als opvolger van Barry in Willoughby's naam bestuurde, was genoodzaakt, haar over te geven en deed nu zijn uiterste best, de kolonisten over te halen, haar te verlaten. Het recht daartoe hadden zij ongetwijfeld; art V van de voorwaarden van overgave ${ }^{1}$ ), vastgesteld door Abraham Krijnssen en William Byam op 6 Maart van het vorige jaar luidde:

„In cas eenige inwoonders van deese colonie 't avond ofte morgen intentie hebben om van hier te vertrecken, soo sal hij vermogen sijne goederen te vercoopen, ende den Gouverneur sal in soodanigen geval maecken, dat hij midts redelijcke vracht gevende, met sijne goederen getransporteert wort".

De voorwaarden van overgave zouden ten spoedigste naar Zeeland gezonden worden, om door de Staten van dit gewest te worden geratificeerd; deze maakten echter met de racificatie niet veel haast, want bericht ervan was nog niet ontvangen, ofschoon sedert de overgave reeds twaalf schepen uit Zeeland waren aangekomen ${ }^{2}$ ).

„....Willoughby was ordered to pay full compensation to the Dutch for all damage done and all goods taken away. He was also to bear the entire cost of transporting back to Surinam any settlers who had been intimidated into leaving, and who wished to return - all this on pain of the King's „high indignation”.

Het is zeer twijfelachtig, of aan dat bevel omtrent schadevergoeding en het terugvoeren der emigranten, aangenomen dat er waren, die den wensch daartoe te kennen gaven, voldaan is. Van die „high indignation" van den Koning, ook weer aangenomen, dat die inderdaad bestond, zullen de Willoughby's zich wel niet veel aangetrokken hebben. Karel II had in Europa aan genoeg moeilijkheden het hoofd te bieden, als hij zich daarvoor eens de moeite gaf, om zich erg druk te maken over wat aan de overzijde van den Oceaan geschiedde. En de Willoughby's hadden in de West genoeg aanhangers om te maken, dat zij voor die verontwaardiging van hun koninklijken meester vrij onverschillig konden zijn. Maar tegenover de Staten kon Karel II wel niet veel anders doen, dan zich zeer verontwaa rdigd(!) toonen.

1) Enc. van Ned. West-Indië, blz. 434, waar het geheele verdrag te vinden is.

2) F. Cundall, The Migration. 
Banister intusschen handelde, alsof hij en niet Abraham Krijnssen Gouverneur was; zijn optreden maakte, dat hem een boete van 9.500 \% suiker werd opgelegd en, dat hij ten slotte gevankelijk naar Zeeland werd opgezonden. In de Republiek aangekomen, beriep Banister zich op den Engelschen gezant Downing ${ }^{1}$ ), door wiens tusschenkomst hij kort na zijn aankomst weer in vrijheid werd gesteld.

Dit feit, de gevangenneming van Banister, en de beschuldiging, dat aan Engelsche onderdanen, in strijd met de voorwaarden van overgave, moeilijkheden in den weg werden gelegd, als zij Suriname wilden verlaten, werden enkele jaren later aangevoerd als reden voor de oorlogsverklaring in 1672 .

Byam, de Oud-Gouverneur, volgde intusschen op zijn nieuwe standplaats Antigua met belangstelling de ontwikkeling der gebeurtenissen in Suriname. Hij schreef omstreeks dien tijd aan Lord Willoughby, dat het ongetwijfeld een treurige kolonie zou worden, als de Engelschen haar verlieten, wat zij gaarne zouden doen, als zij hun schulden konden regelen. De negers zouden in dat geval spoedig de baas zijn.

Krijnssen was inmiddels vertrokken, na het bestuur aan zijn vroegeren onderbevelhebber, Philip Julius Lichtenberg ${ }^{2}$ ) te hebben overgegeven. (16 Februari 1669). Een hoog denkbeeld had deze van de achtergebleven En-

1) Sir George Downing had in Juni 1671 den bekenden gezant Sir William Temple vervangen.

$\left.{ }^{2}\right)$ Jonker Philip Julius Lichtenberg werd in 1637 te Heusden geboren, als zoon van Michiel van Lichtenberg, die vermoedelijk uit Stettin afkomstig, in Staatschen dienst getreden was. Deze bereikte den rang van Luitenant-Kolonel en werd, na eerst te Heusden in garnizoen gelegen te hebben, benoemd tot Commandant van de vesting Hulst. Hij huwde twee maal, eerst in 1637 met Martha Ramsay, die in 1660 stierf en daarna te Zierikzee met Genoveva de Huybert. Jonker Philip Julius was de eenige zoon uit dit tweede huwelijk. Na het licentiaat in de rechten behaald te hebben, trad hij in krijgsdienst, waarin hij zijn loopbaan eindigde met den rang van Luitenant-Kolonel. Als Kapitein nam hij deel aan de expeditie van Abraham Krijnssen.

In Januari 1671 had hij wegens ziekte ontslag als Gouverneur van Suriname verkregen. Hij stelde echter zijn vertrek vandaar uit tot de zaken met betrekking tot het vertrek der Engelschen beëindigd waren. Maart 
gelschen niet. Dit blijkt uit eenige uitlatingen omtrent hen in een brief, dien hij 24 Februari 1671, dus kort voor zijn vertrek, aan de Staten-Generaal schreef.

Volgens hem hadden 60 à 70 personen zich opgegeven om te vertrekken, waaronder slechts drie, die onder de fatsoenlijke menschen gerekend werden. Een had een „suikerwerk” en de rest was maar een hoop ,seer gering volck". Hij voorziet dan ook geen schade door het vertrek der Engelschen: er zou geen pond suiker minder in de kolonie gemaakt worden ${ }^{\mathbf{1}}$ ).

Het lijkt wel wat al te optimistisch. In Engeland en vooral op Jamaica dacht men er anders over. Nadat hij was losgelaten uit zijn kortstondige gevangenschap in de Republiek, was Banister in Engeland, waarheen hij zich begeven had, benoemd tot Generaal-Majoor der krijgsmacht op Jamaica, volgens welke benoeming hij onmiddellijk onder den Gouverneur en den Luitenant-Gouverneur in deze kolonie stond.

Nadat vanwege de Britsche regeering geprotesteerd was tegen het, volgens haar onrechtmatig, vasthouden harer onderdanen in Suriname, werd door de Staten-Generaal toestemming gegeven tot een onderzoek ter plaatse door Engelsche Commissarissen. Op het verzoek, dat in deze commissie Banister niet benoemd zou worden, sloeg de Britsche regeering geen acht. Integendeel hij werd als voornaamste lid naar Suriname afgevaardigd, waar hij trouwens nog particuliere belangen had, en vertrok 15 November met de "America" en twee andere schepen van Londen ${ }^{2}$ ). De „America” kwam den 19en Januari

1671 gaf hij het bestuur over aan Pieter Versterre en vertrok den 25en dier maand via Tobago naar de Republiek.

$\mathrm{Na}$ zijn terugkomst uit Suriname kwam hij eerst in garnizoen te Sluis en werd daarna Commandant van Willemstad. In October 1673 werd hij bij een aanval op Woerden gewond en nogmaals in $1674 \mathrm{bij}$ Seneffe.

(Maandblad De Nederlandsche Leeuw 1899, kolom 193).

1) Zie hierachter Bijlage I.

2) De commissie bestond uit tien leden. Voor het nemen van geldige besluiten was de aanwezigheid van drie ervan noodig, n.l.van Banister, FrancesYates of Christopher Rendar. De laatste, die blijkbaar toen nog niet gereed was met het regelen zijner zaken in Suriname, bleef, nadat de commissie haar taak volbracht had, daar achter. In September 1673 tijdens 
van het volgende jaar voor de Suriname-rivier en drie dagen later ging Banister aan land, om een onderhoud met Lichtenberg te hebben. Inmiddels was een der andere schepen, de ,Joanna” daar ook aangekomen ${ }^{1}$ ).

In Juni 1669 had Lichtenberg ter kennis van de Engelschen gebracht, dat zij, die het plan hadden te vertrekken, daarvan kennis behoorden te geven binnen 6 maanden. Zij kregen dan wederom 6 maanden tijd, om hun zaken te regelen en konden na afloop daarvan een vrijgeleide verkrijgen, om naar een andere kolonie te vertrekken. Slaagden zij er niet in, binnen dien tijd hun slaven van de hand te doen, dan zouden deze door het Hollandsche Gouvernement tegen marktprijs worden overgenomen. Deze laatste bepaling had echter alleen betrekking op die negers, welke bij de overgave aan Krijnssen hun eigendom waren; later aangekochte slaven zouden moeten worden achtergelaten, indien er geen koopers voor te vinden waren. Tijdens de uitvaardiging van de publicatie was juist de marktprijs der slaven toevallig zeer laag. Een en ander zou dus een ernstig verlies voor vermogende plantage-eigenaars beteekenen.

Daarbij kwam nog, dat deze er weinig voor voelden, hun gronden met de erop staande gebouwen eenvoudig te verlaten. $Z$ ij wilden ze natuurlijk verkoopen, maar er deden zich geen koopers op, met wie de eigenaars tot zaken konden komen. Trouwens, dat was niet te verwonderen. Het gold hier niet den verkoop van enkele plantages, maar eigenlijk van vrijwel het geheele in cultuur gebrachte gebied.

Dit maakt het verklaarbaar, dat de meeste Engelschen, vooral eigenaars van bloeiende plantages, aarzelden en, dat er over het algemeen weinig aandacht aan de publica-

het bewind van Pieter Versterre als Gouverneur a/i. na het vertrek van Lichtenberg was hij daar nog, zwaar ziek en in gevangenschap in verband met den inmiddels uitgebroken oorlog van 1672 .

1) 27 Februari 1671 berichtte Lichtenberg aan de Staten-Generaal: „.... . Nadat wij den Major Bannister alhier lange tegemoet hebben gezien, so is hij ten langen leste den 19 January in de rivier als eerste commissaris van den Coninck aangekomen.... De brief, waarin dit voorkomt, bevindt zich in het R. A. in Zeeland (Zie „De Navorscher”' 1918, blz. 102). 
tie geschonken werd. Met eenigen schijn van waarheid kon daardoor aan de Britsche regeering bericht worden, dat de Engelschen met het Hollandsche bewind tevreden waren en geen neiging toonden, te vertrekken.

Banister ${ }^{\mathbf{1}}$ ) had inmiddels niet stil gezeten en het resultaat zijner bemoeiingen was de zending der boven vermelde commissie $^{2}$ ). Met open armen werd deze niet door Lichtenberg ontvangen; integendeel, Banister werd na zijn aankomst scherp in het oog gehouden en, toen hij de rivier opzeilde, om een bezoek aan zijn eigen plantage te brengen, zond de Gouverneur hem een gewapend vaartuig achterna, om te beletten, dat hij eenige pressie op de planters uitoefende.

In weerwil hiervan bereikte Banister ten deele zijn doel. Na een verblijf van $1 \frac{1}{2}$ maand in Suriname (19 Januari-28 Februari 1671) was de commissie erin geslaagd,

1) Banister werd op 10 November 1674 in Jamaica vermoord.

2) Haar opdracht was:

1. Zich zoo spoedig mogelijk naar Suriname te begeven en daar het vertrek der Engelsche onderdanen in overleg met den Hollandschen Gouverneur te regelen. Ter legitimatie moesten de missives der Staten-Generaal en de Instructie van Z. M. aan den Gouverneur ter inzage gegeven worden.

2. Te bevorderen, dat aan Banister, of aan iemand anders, die goed in de kolonie bekend was, bevoegdheid gegeven werd, den planters de voordeelen van hun vertrek uiteen te zetten.

3. Aan de planters mede te deelen dat, zoo zij besloten te vertrekken, in een andere Britsche kolonie gronden en provisiën voor hen beschikbaar waren.

4. Erop aan te dringen, dat de tijd, dien Lichtenberg voor aanmelding tot vertrek beschikbaar gesteld had, verlengd werd.

5. Toezicht te houden op de betaling van schulden aan de Engelschen.

6. Met de noodige voorzichtigheid, ter voorkoming van moeilijkheden met het Bestuur der Republiek, erop toezien, dat hun, die wilden vertrekken, geen moeilijkheden in den weg gelegd werden.

7. Zoo er geen plaats in de schepen was, om allen te vervoeren, andere erbij te huren.

8. Van eventuëel gerezen verschillen, onmiddellijk naar Engeland bericht te zenden.

9. Zoodra de schepen volledige lading aan boord hadden, ze naar Jamaica, of eenig ander Britsch eiland te doen vertrekken.

10. Van de verrichtingen rapport aan den Koning uit te brengen.

Niet alle afschriften der Instructie, die den Commissieleden verstrekt werden, waren eensluidend.

In sommige werd niet Jamaica, maar Barbados, St.-Kitts, of eenig ander Britsch eiland genoemd, als plaats van bestemming der emigranten. 


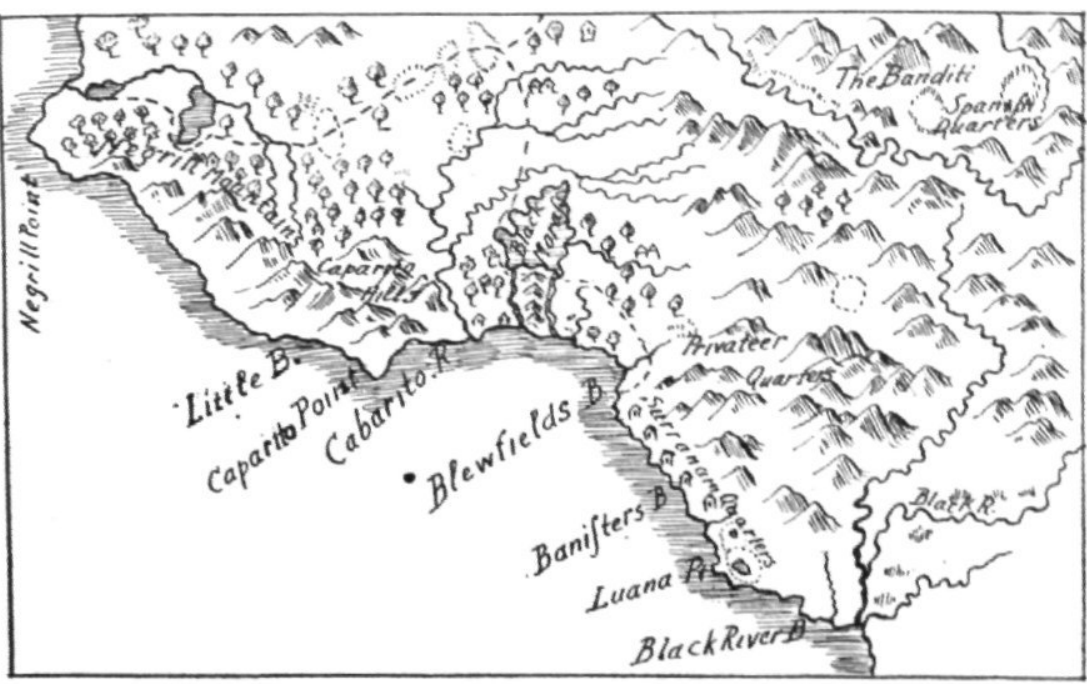

De Z.W. kust van Jamaica,

naar een kaart van Edward Slaney 1678.

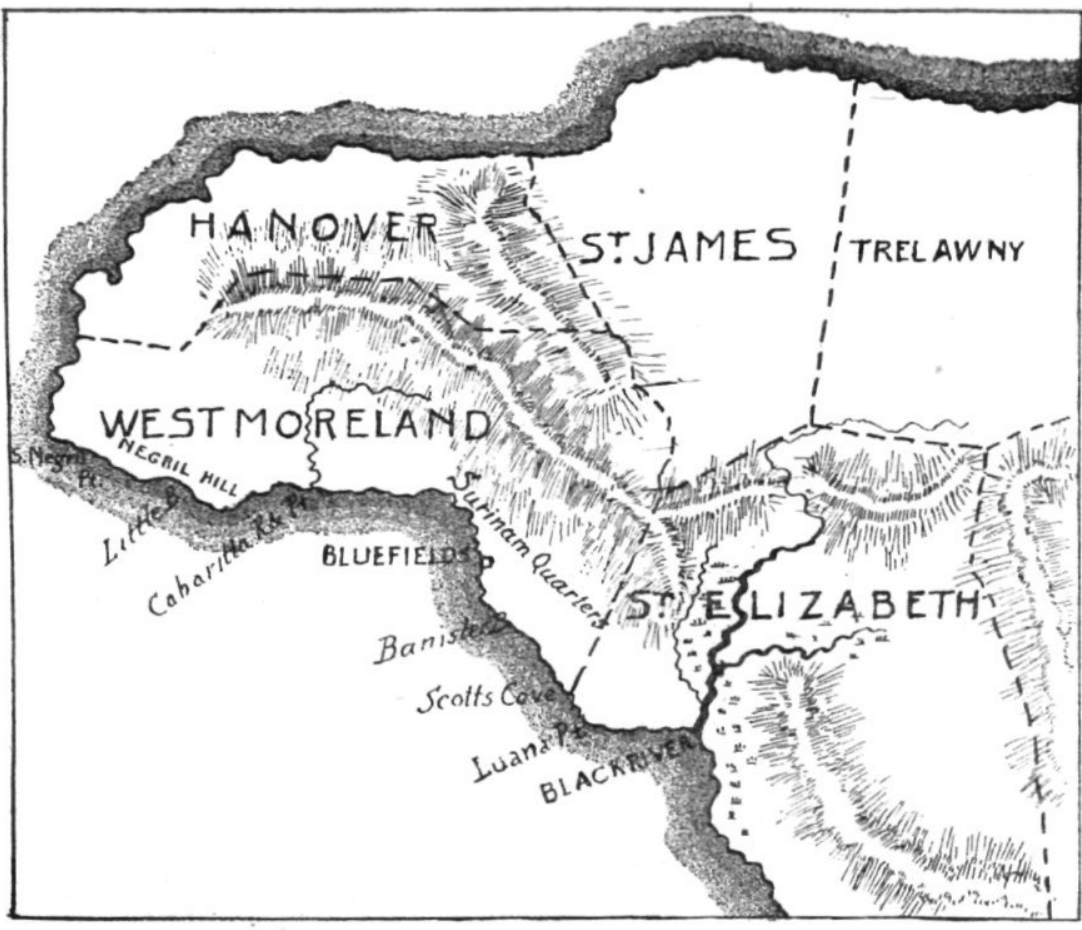

Het W. deel van Jamaica.

naar "Jamaica in I924". door Frank Cundall. 
twee der Britsche schepen, de America en de Joanna, met emigranten te doen vertrekken. De America ging rechtstreeks naar Jamaica, waar zij 12 Maart aankwam en 105 families, tezamen tellende 517 personen aan land zette. De Joanna zeilde eerst naar Barbados, waar 3 families afgezet werden en begaf zich vandaar eveneens naar Jamaica.

Daar werden de immigranten met open armen ontvangen, wat geen wonder is. De Gouverneur Sir Thomas Lynch ${ }^{1}$ ) wees hun als vestigingsplaats een streek aan, gelegen aan de $Z$. W. kust van het eiland, die thans nog als "The Surinam Quarters" bekend is. Kort na de verovering op de Spanjaarden in 1655 door Penn en Venables was men op Jamaica met de suikercultuur begonnen. De Surinaamsche planters, die met die cultuur uitstekend bekend waren, konden den bloei ervan natuurlijk ten zeerste bevorderen ${ }^{2}$ ).

1) In 1670 was de Gouverneur Sir Thomas Modyford vervangen door Sir Thomas Lynch.

Modyford was een neef van George Monk, hertog van Albemarle, den hersteller der Stuarts. Aanvankelijk royalist, verklaarde Modyford zich in 1651 voor het Parlement. In 1660 werd hij tot Gouverneur van Barbados benoemd en vertrok kort daarna, nadat hij door Willoughby vervangen was, naar Jamaica. Hier werd hij door invloed van Albemarle 15 Februari 1664 tot Gouverneur benoemd. De dood van zijn beschermer in 1670 veroorzaakte zijn val.

In 1670 werd Sir Thomas Lynch uitgezonden met opdracht, Modyford te arresteeren en hem ter verantwoording wegens machtsmisbruik en bevordering van de zeerooverij naar Engeland op te zenden. Bij het uitvoeren van die opdracht verzekerde Lynch zich van de medewerking van Banister. Een der punten van beschuldiging tegen Modyford was zijn bevordering van het bedrijf der flibustiers. Hun aanvoerder Henry Morgan werd tegelijk met Modyford gevangen genomen en met het fregat „Welcome” naar Engeland gezonden.

Banister en de Raad van Jamaica dachten over de flibustiers en hun aanvoerder anders, dan men dat in Engeland deed. In Maart 1671 althans schreef Banister naar het moederland met betrekking tot Morgan, dat deze in Jamaica algemeen beschouwd werd, als ,a very well deserving person and one of great courage and conduct, who may with His Majesty's pleasure perform good public service at home or be very advantageous for this island, if war should again break forth with the Spaniards".

Deze aanbeveling en de bescherming, die Morgan in Engeland genoot, maakten, dat hij ten slotte weer in de koninklijke gunst geraakte. Karel II verhief hem in den adelstand en in 1674 werd hij als kolonel met den opvolger van Lynch, Lord Vaughan weer naar Jamaica gezonden.

2) Zie o.a. blz. 14 W. I. G. VIII 1. 2. 
Inmiddels hadden zich in Europa belangrijke gebeurtenissen afgespeeld. Slechts vier jaar zou na den 2en Engelschen oorlog de vredestoestand met Groot-Brittannië standhouden. De stemming van Frankrijk ten opzichte van de Republiek was voortdurend vijandiger geworden en bij het geheim Verdrag van Dover (Juni 1670) had Engeland zich verbonden, de Triple Alliantie te verbreken en één lijn met Lodewijk XIV te trekken. Den 7en April 1672 verklaarden Frankrijk en Engeland den oorlog aan de Republiek en den 18en van de volgende maand kwamen de oorlogsverklaringen van Munster en Keulen.

In de oorlogsverklaring werd o.a. als motief daarvoor vermeld het gebeurde in Suriname ${ }^{\mathbf{1}}$ ).

Volgens de Britsche regeering had deze langen tijd getracht, door vreedzame middelen den voorspoed van het Koninkrijk te bevorderen. Britsche onderdanen buitenslands hadden echter steeds te lijden gehad van onderdrukking door onze Republiek. Dat had reeds geleid tot den oorlog van 1665-1667, waarin de Koning zulke overwinningen behaald en de Republiek zoodanige nederlagen geleden had, (sic!) dat verwacht mocht worden, dat de laatste althans de vredesvoorwaarden eerlijk zou nakomen. Het tegendeel was echter het geval geweest. In Indië liet men de zaken op haar beloop en in de West werd aan Britsche onderdanen in strijd met de voorwaarden be let, vandaar te vertrekken. De laatsten smeekten den Koning, tusschenbeide te komen, om hen uit die slavernij te verlossen, maar brieven aan de Staten-Generaal daarover werden door deze eenvoudig niet beantwoord.

Dat was de Britsche voorstelling van de zaak en het is niet te verwonderen, dat de motieven voor de oorlogsverklaring waarop men in de Republiek totaal niet was verdacht geweest, heftige verontwaardiging wekten. In een pamphlet uit dien tijd (zie hierachter, bijlage III) werden zij gesignaleerd, als „tastelijke onwaarheden, quaataardige misduydingen en grove impertinentiën". Volgens dit pamphlet was het „visibel, dat den oorlogh van den

1) Zie hier achter Bijlage II. 
Hoog-gemelden Koning nergens anders uyt voorkomt, als uyt een geformeert dessein, om de palen van syn gebiet so verre uyt te strekken, als syne ambitie is geëxtendeert".

Hoewel het laatste ongetwijfeld waar was, althans, wat de West betreft, kan het toch niet ontkend worden, dat, de overdrijving buiten rekening gelaten, de Britsche voorstelling der zaken niet geheel onwaar was. De kwestie was voor onze autoriteiten nu eenmaal hoogst moeilijk. Werd art. V van de overeenkomst tusschen Krijnssen en Byam letterlijk nageleefd, dan zou dit beteekenen, dat de kolonisatie van Suriname van den grond af moest worden opgebouwd, wat ten zeerste zou worden bemoeilijkt doordat de planters met hun kapitaal en ervaring in Engelsche nederzettingen, in het bijzonder in Jamaica, haar een doodende concurrentie zouden aandoen. Hierop legde men het van Britsche zijde ongetwijfeld aan. Het was dus volkomen begrijpelijk, al is het niet geheel eerlijk te noemen, dat de Hollandsche autoriteiten alles in het werk stelden, om den ondergang van de kolonie te voorkomen ${ }^{1}$ ).

1) Engelsche schrijvers geven toe, dat de toeleg der Britsche koloniale autoriteiten erop gericht was, Suriname te gronde te richten.

James Rodway schrijft o.a. in een voorwoord bij het opstel van Frank Cundall „The Migration from Surinam to Jamaica” het volgende:

"The story of the evacuation of Surinam by the British is peculiarly interesting, for nothing like it appears to have been recorded in history. We read of many surrenders of islands and other colonies, where combatants have been allowed to leave, but not where practically a whole colony wanted to go off with their slaves and effects.

It was almost a desertion, the main object of the British authorities being to leave Surinam as bare as it was, when there was no colony at all. That the Dutch did not like this goes without saying, and that they tried their best to prevent such a removal could only be expected.

(Cursiveering van mij K.).

Zie van denzelfden schrijver „Guiana: British, Dutch, and French" London en Leipzig 1912 bl. 69 blg. en „The West Indies and the Spanish Main”. London 1899, waarin uitvoerig over deze kwestie wordt gehandeld.

Een andere Engelsche historicus, Vincent T. Harlow, 1.c. blz. 186 merkt omtrent de herovering en plundering van Suriname het volgende op:

„Unable to keep Surinam himself, Lord Willoughby determined that no one else should. He ordered his son Henry to return without loss of time and to do his utmost to induce the English settlers, who had been re-established there, to embark with all their movables for Antigua. This course, 
Inmiddels gingen de zaken in Europa haar gang en de loop van de krijgsverrichtingen en de binnenlandsche politieke gebeurtenissen in zijn koninkrijk noodzaakten Karel II zijn bondgenootschap met Frankrijk op te geven en onderhandelingen met de Republiek aan te knoopen. Den 19en Februari 1674 kwam de tweede vrede van Westminster tot stand, waarbij ten opzichte van Suriname o.a. bepaald werd, dat de Koning het recht zou verkrijgen, een commissie daarheen te zenden, om den toestand van Britsche onderdanen te onderzoeken, den tijd van hun vertrek vast te stellen en voor het vervoer van henzelf, hun slaven en goederen schepen erheen te zenden.

In Maart 1674 werden de hiertoe te nemen maatregelen besproken in een vergadering van de Lords of Trade and Plantations. Deze adviseerden, den Koning de noodige stappen aan te bevelen, ten einde de Engelschen met hun slaven en goederen, ten getale van ongeveer 700 uit

he felt assured, would utterly disable the Dutch from settling that colony". (N. 1. Suriname. - Cursiveering van mij. K.).

Het volgende is niet meer dan een uitvlucht van Henry Willoughby, om gelegenheid te krijgen met zijn werk van verwoesting door te gaan:

„When the Dutch captain Du Bois (n.l. Jan van Houtte, gezegd Du Bois, die met 3 schepen en een snauw naar Suriname gezonden was, najaar 1667) arrived with a fleet and demanded the surrender of the colony, Henry refused although shown an order of King Charles to that effect, on the ground that no such order had been received by the Governor of Barbados. (Cursiveering van mij. K.).

(Vincent F. Harlow, M. A., B. Litt. A History of Barbados. Oxford, 1926).

Het schijnt eenigszins vreemd, dat voor de vestiging der, uit Suriname weggevoerde, planters niet in de eerste plaats Barbados, maar wel Antigua en later vooral Jamaica in aanmerking kwam. De verklaring hiervan zal wel hierin zitten, dat de verhouding der Willoughby's tot Barbados van karakter veranderd was. Lord Francis had het eiland gepacht van den Graaf van Carlisle, die zijn eigendomsrecht grondde op een Koninklijken giftbrief van 1624, waarbij alle Caraïbische eilanden hem werden toegewezen. Na de Restauratie evenwel, was deze giftbrief ingetrokken en hadden de Willoughby's dus niet meer in de eerste plaats belang bij den bloei van Barbados. Dit was niet meer een „patroons” kolonie, maar meer een „crown colony" geworden. De Gouverneur werd voortaan door den Koning benoemd. Daarentegen begon Jamaica meer en meer belangrijk te worden, vooral sedert bij het Verdrag van Madrid in 1670 Spanje zijn aanspraken daarop had opgegeven en kort daarna, na de stichting van de „Royal African Company" (1672) het eiland als slavenmarkt en omstreeks dienzelfden tijd ook voor de suikercultuur van belang werd. (Omstreeks 1673). 
Suriname te doen wegvoeren. In het begin van Juni volgde daarop een bevel van den Koning aan den Council, één of twee personen aan te wijzen, die met die opdracht zouden kunnen belast worden. De Raad beval aan Fernando Gorgas van Barbados en William Stede. In plaats van den laatste wenschte de Koning echter een zijner ,gentlemenushers" met de zending te belasten, nl. Edward Cranfield. De Staten-Generaal verstrekten paspoorten voor Cranfield en Gorgas, doch de laatste werd later vervangen door Mark Brent (Marcus Brandt). En ten slotte werd aan de commissie nog toegevoegd de gezagvoerder van een der schepen, het fregat „Hunter”, n.l. Edward Dickenson. De commissie, die 28 Maart 1675 haar instructie van den Koning ontving, bestond dus uit Edward Cranfield, Marcus Brandt en Edward Dickenson.

De voornaamste punten uit de instructie waren de volgende:

1. De planters over te halen, liever naar een andere Britsche kolonie te verhuizen, dan naar Engeland.

2. Aan Cranfield werd opgedragen, voor hun overtocht zorg te dragen en daaromtrent aan de Regeering rapport uit te brengen.

3. Verder moest hij St.-Kitts bezoeken en rapport uitbrengen omtrent de daar heerschende verschillen tusschen Engelschen en Franschen.

4. Als plaats van bestemming der emigranten werd Barbados uitgezonderd, omdat daar al het beschikbare land reeds was uitgegeven.

5. Zoo mogelijk moesten allen naar Jamaica vervoerd worden. Cranfield werd gemachtigd, den emigranten toe te zeggen, dat zij daar de dubbele oppervlakte land konden krijgen, die gewoonlijk werd uitgegeven, nl. $2 \times 30$ acres.

Op 6 April 1675 vertrok de commissie van Jamaica. De leden ervan waren aan boord van de adviesboot „Henry and Sarah", die vergezeld werd door twee gehuurde schepen, de „America” en de „Hercules”. Het eskader werd geconvoyeerd door het fregat „Hunter” onder commando van Edward Dickenson. De adviesboot zeilde het snelst 
en kwam reeds op 28 Mei op de Suriname-rivier voor anker; de overige schepen arriveerden den 3en Juni d.a.v.

Toen alle schepen aanwezig waren, maakten de Commissarissen op 4 Juni hun opwachting bij den Gouverneur a.i. Pieter Versterre en boden hem hun geloofsbrieven aan.

Den 7en d. a. v. werd in een publicatie, die in het Hollandsch en in het Engelsch gesteld was, bekend gemaakt dat Engelsche schepen aangekomen waren, om hen, die wilden vertrekken, af te halen en tevens aangekondigd, dat den 10en derzelfde maand in een gecombineerde vergadering van den Gouverneur en twee Raden van Politie met de leden der Commissie alle te nemen matregelen zouden worden besproken ${ }^{\mathbf{1}}$ ).

Volgens rapport van de Commissie aan den „Principal Secretary of State" Sir Joseph Williamson werd in deze vergadering de gewenschte overeenstemming bereikt. Allen zouden vergunning verkrijgen te vertrekken, met uitzondering van twee of drie weezen, die aan de zorgen van Gouverneur en Raden waren toevertrouwd.

In een aanhangsel wordt onder denzelfden datum echter tevens bericht, dat er verschil was ontstaan over de vraag, of ook Joden recht hadden te vertrekken en, of Indiaansche bedienden (geen slaven) mochten worden mede gevoerd.

Er is eenige aanleiding, te vermoeden, dat Versterre van meening was, dat Joden niet in de overeenkomst behoorden te worden begrepen en, dat het geenszins zijn bedoeling was, de Commissie opzettelijk hindernissen bij het volbrengen van haar taak in den weg te leggen. Dit zou men althans kunnen opmaken uit de volgende aan-

1) In deze publicatie werd den kolonisten aangekondigd, dat zij konden worden overgevoerd naar Engeland, een der Caraibische eilanden of Jamaica met „your families, servants and Merchandises and all your Conveniences for the making of Sugar and Indigoe".

Jamaica wordt bijzonder aanlokkelijk voorgesteld. Daar zou hun worden gegeven ,double the quantity of land, that is usually allowed to other Planters", en men zou ,take care that you be furnished with provisions and other necessaries at moderate cost, if you want, till you shall be able to produce them your Selves". 
haling uit een brief van Versterre, gedateerd 4 Juli 1674: „.... het getal van de Engelsche natie hier in dese collonie in 't generael is off wort gereeckent op hondert en twintich families, ende daervan maecke staedt dat tachentich sullen vertrecken, voor sooveele ons voor 't meerendeel bekent is, waeronder gereeckent acht suyckerwercken, gelyck UEd. in de lyste geannoteert vinden, maer worden alle op twee naer, wederom by de duytsche ende Joodsche natie beseeten, soodat wy in dien reguarde wel niet veele en verliesen, maer ten aensien van de goede en bequaeme planters, so kryght de collonie van Suriname een grooten krack" 1).

Het is echter ook mogelijk, dat de wd. Gouverneur reeds toen hij dit schreef in het bezit was van instructies van zijn lastgevers, de Joden in geen geval te laten vertrekken, maar voorloopig trachtte hij zich te verschuilen achter de twijfelachtige positie, waarin deze verkeerden. Hij verklaarde zich bereid, Engelschen te laten vertrekken, maar beweerde, dat Joden niet als Britsche onderdanen mochten beschouwd worden. Van hare zijde voerde de commissie daartegen aan, dat, als het woord onderdanen alleen van toepassing verklaard werd op Engelschen, Schotten en Ieren ook zouden dienen te worden uitgesloten. Tegen hun vertrek was echter geen bezwaar gemaakt.

Versterre was inderdaad in een moeilijk parket. Zijn streven was ongetwijfeld, de zaken op vredelievende wijze te regelen ${ }^{2}$ ); hij moest toegeven, dat de tegenwerping der

1) Deze brief met een „Lijste van Engelsen, die van meening syn uit dese colonie te vertrekken" (welke lijst 77 namen bevat) bevindt zich in het Rijks-Archief in Zeeland. Hij was vermoedelijk gericht aan Pieter de Huybert, destijds Raadpensionaris van Zeeland. (In de „Navorscher” LXVI, 1917 gepubliceerd door F. E. baron Mulert).

Mr. Pieter de Huybert, Heer van Burgh en Kraayenstein (geb. 1622 te Middelburg en overl. 1697 te 's-Gravenhage) bekleedde verschillende aanzienlijke ambten in Zeeland. Hij was verschillende malen gezant van $\mathrm{HH}$. Hoogm. en was 1664-1687 Raadpensionaris van Zeeland. In 1667 was hij gevolmachtigde van de Staten bij de onderhandelingen over den vrede van Breda.

2) Dit blijkt uit de volgende passage uit den brief van Versterre van 14 Juli 1674:

.... de Engelsche commissarissen hier binnen gecomen synde, is by ons 
commissie juist was, en was ten slotte wel genoodzaakt mede te deelen, dat hij brieven uit Zeeland had ontvangen, waarin het vertrek der Joden verboden werd. Op het verzoek der commissie, deze te mogen inzien, ontving zij een weigerend antwoord.

Er bleef haar dus voorloopig niets anders over, dan tegen deze beslissing van den Gouverneur officiëel te protesteeren. Dit protest, waarin als motief voorkomt: „haueing given a flatt deniall concerning $\mathrm{y}^{\mathrm{e}}$ remouall of $\mathrm{y}^{\mathrm{e}}$ Hebrew Nation \& free Indians, $\mathrm{y}^{\mathrm{t}}$ are Domesticks \& belonging to his $\mathrm{Ma}^{\text {ts }}$ Subjects, haueing lived many yeares in their families", werd den Gouverneur voorgelezen door den klerk $\mathrm{Jn}^{\circ}$. Millet in tegenwoordigheid van $\mathrm{Ri}$ chard Scott, Andrew Knight en Hierome Westhorpe, als getuigen. De beide laatsten waren voorname planters in Suriname.

Den 12en Augustus gingen de schepen onder zeil; aan tien Joodsche planters was het vertrek verboden. Dit waren de volgenden: Isaac Perera, Jacob Perera, David Perera, Isaac de Meza, Aaron de Sylva; Isaac Govia, Gabriel Antonius, Moses Baruch en Benjamin Perera, te zamen met 322 slaven ${ }^{\mathbf{1}}$ ). Afschrift van het protest der commissie werd bij het rapport harer verrichtingen gevoegd.

Toen dit te Londen ontvangen was, werd het op $11 \mathrm{Fe}-$ bruari 1675 in den Raad des Konings behandeld en werd besloten, dat Sir Joseph Williamson de zaak zou bespreken met den Hollandschen gezant Van Beuningen en, dat orders gezonden zouden worden aan den Engelschen gezant in de Republiek Sir William Temple, haar met de Staten-Generaal te behandelen.

Op 23 Februari schreef Williamson daarop aan Van

een dagh beraemt, wanneer wy by den anderen sullen komen, om alle differenten en schulden tusschen d'Engelsche ende Duytsche te effenen, 't welck sal wesen op den tienden deser maent July, als wanneer ick hoope ende Godt bidde, dat alles in der minne sal afloopen ende eyndigen, waertoe aen myne syde niet sal manqueeren, alle debvoiren aen te wenden...."

1) In een latere Fransche lijst, die de „Secretary of State” Williamson aan Van Beuningen toezond, staat Isaac de Meza vermeld als Isaac de la Paxa en wordt het aantal slaven van Gabriel Antonius (of Antonnis) opgegeven als 25 . (In de eerste opgave 15). Het totaal der slaven wordt daardoor 332 . 
Beuningen en vermelde onder overlegging van de lijst van namen der Joden met het aantal hunner slaven, „que le gouverneur de Surinam n'a pas voulu donner permission à certains Juifs, sujets de sa $M a^{t e ́}$, de se transporter de la dite Colonie avec le reste des Anglois".

Inmiddels had Cranfield zijn zending volbracht, voor zoover hij daartoe in staat was geweest. Het fregat „Hunter" convoyeerde op de terugreis de andere schepen niet. Volgens rapport van Vaughan, Gouverneur van Jamaica, kwam eerst de „Henry and Sarah” met de commissarissen, 81 emigranten, 120 slaven en 31 Indiaansche bedienden en daarna de beide andere schepen, drie weken later; de „Hercules” met 53 blanken en 449 slaven en de „America" met 116 blanken en 381 slaven aan boord. In totaal werden dus bij die reis uit Suriname weggevoerd 250 blanken met 950 slaven en 31 Indiaansche bedienden ${ }^{\mathbf{1}}$ ).

1) Er bleven, behalve de Joodsche planters, aan wie het vertrek verboden werd, ook nog andere Engelschen achter, die niet tijdig hun financiëele aangelegenheden hadden kunnen regelen.De meeste Engelschen waren weliswâar crêditeuren, mâar er waren er toch ook, wier schulden hun activa overtroffen. Dit was o.a. het geval met een zekeren Wm. Wyatt en met Rowland Simpson. Deze laatste had allerlei kwesties met andere Engelschen o.a. met Andrew Clifford. Diens zoon Jeronimo Clifford, hij moge dan ook niet in alle opzichten rechtvaardig behandeld zijn, bleek in later jaren een echte querulant, die opvolgenden Gouverneurs heel wat last veroorzaakte. Tot 1737, het jaar van zijn dood, was hij in een eindelooze serie processen gewikkeld in verband met een schuldvordering op Simpson en andere daaruit voortvloeiende zaken.

De zaak van Clifford wordt o.a. uitvoerig behandeld in een in 1760 verschenen werk, dat den wijdloopigen titel draagt van:

„The Conduct of the Dutch, relating to their Breach of Treaties with England. Particularly their Breach of the Articles of Capitulation, for the Surrender of Surinam in 1667; and their Oppressions committed upon the English Subjects in that Colony, enz."

De geheele titel beslaat ongeveer een bladzijde en eindigt aldus:

„The whole proving a Series of Facts, authenticated from Papers in the public Offices of State, whereby the Treachery and Injustice of the Dutch, towards the English are displayed in a very interesting Light.

De titelplaat vertoont de Britsche Maagd, leunende op een schild met het opschrift „Justice, Liberty". Zij neemt een stuk in ontvangst van iemand, die voor haar neerknielt (Clifford?) met het opschrift „Breach of Treaties". Op den achtergrond is een zeeman(?) te zien met een stukgescheurd papier, waarop staat „Treaty 1674”

Naast de Britsche Maagd ziet men een engeltje(?), weenende bij een kistje, waarop staat „Amboina, Surinam”.

Op den voorgrond ligt een slapende (Britsche?) leeuw met daarbovenop den Hollandschen Leeuw met pijlbundel. 
$\mathrm{Na}$ een niet zeer aangenaam verblijf op Jamaica vertrok Cranfield naar Engeland, waar hij op 18 Mei 1676 in Whitehall mondeling verslag van zijn verrichtingen in de West uitbracht aan de ,Committee of Trade and Plantations". Bij de vergadering, waarin dit plaats had, was ook Sir Joseph Williamson tegenwoordig, die o.a. vermeldde, dat ", $\mathrm{y}^{\mathrm{e}}$ Hollanders denied that $\mathrm{y}^{\mathrm{e}}$ Jewes were his Maj. ${ }^{\text {ties }}$ Subjects or free Denizins".

Het schijnt, dat de autoriteiten in Engeland verder geen groot belang meer in de zaak stelden. Anders was dat echter in de West-Indische koloniën; daar hield men nog geruimen tijd een afgunstig oog op het eertijds Britsche Suriname gevestigd. En de omstandigheden brachten mede, dat nog wel eens een poging gewaagd kon worden, de achter geblevenen, in weerwil van het verbod van de Staten van Zeeland toch nog weg te voeren.

In 1678 was John Vaughan als Gouverneur van Jamaica ontslagen en vervangen door den Graaf van Carlisle. Deze berichtte in Januari van dat jaar, dat een schip van Suriname komende, door storm naar zijn eiland gedreven was en, dat hij van den schipper vernomen had, dat de Indianen tegen de Hollanders in opstand gekomen waren. De Gouverneur Heinsius ${ }^{\mathbf{1}}$ ) had zich met de Hollanders in het fort teruggetrokken en de Indianen hadden groote verwoestingen op de plantages aangericht, riet en provisiën verbrand en de fabrieken verwoest. De Engelschen hadden willen vertrekken, doch Heinsius had hun dit verboden. Carlisle adviseerde nu, een fregat te zenden, om hen toch weg te voeren.

In Mei van hetzelfde jaar beslisten de Lords of Trade and Plantations, dat dit niet aanbevelenswaardig was, daar er gevaar bestond, dat het te zenden schip in beslag genomen zou worden. Bovendien hadden naar hun meening de Engelschen nu voldoende gelegenheid gehad, zich uit Suriname te verwijderen.

De toestand daar verergerde inmiddels. In Juni 1679 berichtte Atkins, Gouverneur van Barbados, dat Hein-

1) Johannes Heinsius, Oud-Secretaris van den Raad van Justitie in Brazilië. (1678-1680). 
sius hem om hulp tegen de Indianen verzocht had, daar hij anders genoodzaakt zou zijn, de kolonie aan $Z$. M. over te dragen, of haar zou aanbieden aan den Koning van Frankrijk ${ }^{1}$ ). In hoeverre deze mismoedigdheid inderdaad bij Heinsius bestond, is moeilijk uit te maken. De Engelschen deden echter met zijn tegenspoeden hun voordeel, althans in December 1679 berichtte Sir William Stapleton, Gouverneur van Nevis, dat hij een één-mast vaartuig (ketch) had afgezonden om de Engelschen, die nog in Suriname waren, af te halen. Op 7 Februari 1860 kwam dit vaartuig te Antigua aan en zette daar 102 blanke en zwarte passagiers af.

Daarna schijnen geen verderepogingen gedaan te zijn, nog achtergeblevenen weg te voeren. Trouwens veel kunnen er niet meer geweest zijn. Het is duidelijk, dat de Engelsche toeleg gelukt was, om Jamaica ten koste van $\mathrm{Su}-$ riname er boven op te helpen. Het eerste werd weldra een der voornaamste koloniën in de West, ,, a rare pearl of the British crown", zooals het in een rapport uit dien tijd genoemd wordt.

De houding der Hollandsche en Zeeuwsche autoriteiten in deze geheele zaak schijnt moeilijk te verdedigen. Dat zij niet van harte medewerkten, om Engelsche kolonisten te laten vertrekken, is volkomen begrijpelijk en eveneens, dat geen overdreven vrijgevigheid betoond werd met betrekking tot, wat deze wilden medevoeren. De Engelschen wilden b.v. hun machineriëen uit de suikerfabrieken medenemen, waartegen Lichtenberg zich verzette, bewerende, dat deze zaken tot de overgegeven fabrieken behoorden en niet tot de roerende goederen, die vervoerd mochten worden.

Art. V van het verdrag van overgave in 1667 sprak van bevoegdheid, goederen te verkoopen en van vervoer van belanghebbenden met hun bezittingen tegen redelijke vracht. En art. V van het vredesverdrag van Westminster gaf Karel II de bevoegdheid, één of meer schepen te

1) Wolbers vermeldt, dat een voorstel hieromtrent uitgegaan was van de vergadering van den Raad van Politie. (Geschiedenis van Suriname, blz. 51). 
zenden, om Britsche onderdanen met hun goederen en slaven te vervoeren. Welke goederen hierbij bedoeld waren, was niet nader omschreven; het schijnt echter geenszins onredelijk, dat een zoo ruime opvatting daarvan, als de Engelschen, op aansporing van Banister er aan wilden geven, door den Hollandschen Gouverneur niet zonder protest aanvaard werd.

Met betrekking tot de Joden was het geval echter anders. Hierboven werd vermeld, dat Versterre pertinent weigerde, eenigen hunner te laten vertrekken. Als men de geschiedenis der Joden in de Britsche koloniën en in Engeland nagaat, is men aanvankelijk geneigd tot de meening dat Joden door de Britsche regeering niet als onderdanen beschouwd werden. En in verband hiermede is het niet zonder belang op te merken, dat de bewoordingen van art. III van het verdrag van overgave in die zelfde richting wijzen. Hierin toch wordt het behoud van hun bezittingen gegarandeerd aan ,,alle persoonen, wie die oock souden mogen wesen, ende van wat natie die oock souden mogen syn, hetzij Engelschen, Joden, enz". Joden worden dus afzonderlijk, naast Engelschen, vermeld.

In Engeland duurde het tot het midden van de $17 \mathrm{e}$ eeuw, eer Joden weer werden toegelaten, nadat zij sedert 1290 door Eduard I uit het rijk verbannen waren. Dat zij ook toen nog als vreemdelingen beschouwd werden, blijkt uit de bepalingen van de wet van 1753 , die eischte, dat zij zich eerst zou den laten naturaliseeren ${ }^{\mathbf{1}}$ ).

In de Britsche koloniën in Amerika was men een weinig toeschietelijker te hunnen opzichte, al werd het hun ook daar soms moeilijk genoeg gemaakt. Jacobus I b.v. schreef in 1610 voor, dat onder zekere - en voor hen vrijwel onaannemelijke voorwaarden - Joden in Britsche

1) The Whitehall Conference of 1655 marks a change in the status of the Jews in England, for though no definite results emerged, it was clearly defined by the judges, that there was no legal obstacle to the return of the Jews....

No serious attempt towards the emancipation of the Jews was made till the Naturalisation-Act of 1753 , which was, however, immediately repealed.

(The Encyclopaedia Brittanica XV, blz. 409). 
koloniën op het Amerikaansche vasteland konden genaturaliseerd worden, welke bepalingen in 1675 eenigszins en in 1740 nog meer verzacht werden ${ }^{\mathbf{1}}$ ).

Het is algemeen bekend, dat men in onze Republiek ten opzichte der Joden veel liberaler opvattingen huldig$\left.\operatorname{de}^{2}\right)$.

In Suriname was hun toestand tijdens de Engelsche periode vrijwel gelijk aan dien van Britsche onderdanen. Volgens art. 6 van de Proclamatie van Lord Willoughby van 7 Aug. 1665 zouden allen, die zich in Suriname vestigden, beschouwd worden als Britsche onderdanen en moesten wederkeerig gehoorzamen aan alle decreten van den Koning van Engeland, die geen inbreuk maakten op hun voorrechten. Er is dan ook niet veel twijfel aan, of de pertinente weigering van Versterre, hen te laten vertrekken, was onrechtmatig ${ }^{3}$ ).

Was dus op zichzelf beschouwd, deze weigering niet te verdedigen, daartegenover staat, dat de eisch der Engelschen niet ingegeven werd door den wensch, z.g. verdrukte onderdanen te beschermen, maar eenvoudig door dien, zooveel mogelijk de welvaart van Suriname te vernietigen en die van eigen koloniën te bevorderen ${ }^{4}$ ).

Niettemin, baatzuchtige motieven mogen de Britsche regeering hierbij, als in zooveel andere gevallen, waarbij

1) Dr. J. Hollander. Publications of the Jewish Historical Society, No. 5, blz. 104 e.v.

2) Dr. H. Graetz. Geschichte der Juden. X, blz. 3, 27 en 113.

3) Prof. Dr. J. de Louter wiens oordeel ik hieromtrent inriep, schrijft zeer beslist: „.... in elk geval behoorden zij (de Joden K.) tot de inwoners en hadden dus volgens het verdrag van overgave de bevoegdheid zich uit de kolonie te verwijderen...."

En verder: „Stellig waren alle ingezetenen van Suriname, à forteriori inwoners, destijds Britsche onderdanen, onafhankelijk van hun herkomst, geloof of rechtstoestand...."

4) Zie o.a. Dr. J. H. Hollander, Documents relating to the Attempted Departure of the Jews from Surinam in 1675. blz. 6. (Publications of the American Jewish Historical Society. No. 6. 1897).

Deze schrijft hierover: The fact is made strikingly evident that the same government which denied the privileges of a British subject to a Jew, even though born or long resident on English soil, was quick enough to merge all distinctions and to insist that Jews resident in Surinam were British subjects, when manifest advantage lay in doing so.

(Cursiveering van mij. K.). 
zij tegen de Republiek in de 17e eeuw optrad, geleid hebben, het is niet te ontkennen, dat de houding der Zeeuwsche en Surinaamsche autoriteiten in deze kwesties al evenmin fraai was. De Gouverneurs van de verschillende koloniën in dien tijd in de West maken in sterke mate den indruk als van winkeliers, die op geoorloofde of ongeoorloofde wijze lastige concurrenten willen wegwerken.

Duistere bladzijden in de geschiedenis van Suriname waren het zeker en het heeft tientallen van jaren geduurd, eer de kolonie den toegebrachten slag te boven was.

Nieuwer-Amstel, November 1928. 


\section{BIJLAGE I}

Uit een brief van J. Ph. Lichtenberg aan de Staten Generaal.

24 Februari 1671.

.... Onder het getal van 98 personen, die sich aangegeven hebben (uit wysende dese lyste) om van hier te vertrekken, bevonden sich niet meer als drie, die hier onder de fatsoenlycke luyden gereeckent worden en onder deselve een eenige, die hier een suyckerwerck heeft, synde de rest maer een hoop seer gering volck, waaronder het getal van tusschen de 60 en 70 sterk met hun allen niet één neger kunnen uytmaecken, hetwelk een pure schurftige canaille is, die sich meest met bedelen onder de Indianen opgehouden heeft, daer men reden toe soude hebben om te wenschen van ontslagen te syn, indien het land wat meer gepopuleerd was, sodat de schade, die Bannister hun sal komen te doen van geenige de minste importantie is, sullende om dit, van de weynige Engelschen niet een pont suycker te minder in de colonie gemaeckt worden, also alle de plantagiën van eenige natie van de afgaende Engelschen by duytsche plantagiën syn ingekocht.

(Deze brief, gepubliceerd in de Navorscher 1918 blz. 102-110, door F. E. Baron Mulert bevindt zich in het R. A. van Zeeland.

De lijst, die erin vermeld wordt, is niet aanwezig).

\section{BiJLAGE II}

L. Sylvius. Historien onses Tijds, Behelzende Saken van Staat en Oorlogh. Begindt 1669 en Eyndigt 1679.

Blz. 193. „bevindende dat het ydel was de prosperiteyt van ons Koningryk voort te setten door vreedsame middelen, terwyl onse Onderdanen geduurig onderworpen waren de injurien en oppressien van dien Staet buyten Lands...."

....,Hierop volgde den Oorlog in den Jare 1665, welke duurde tot den Jaere, 1667 in welcke tydt onse Victorien en haer verliesen Haer genoegsaem behoorden gedagtig te maken in 't toekomende haer Verbond oprechtelyk te onderhouden...."

Opsomming der Engelsche grieven, die als voorwendsel dienden voor de oorlogsverklaring in 1672.

1. (Er waren door de Staten-Generaal geene commissarissen gezonden om den Oost-Indischen handel te regelen en de daaromtrent bestaande verschilpunten uit den weg te ruimen).

2. In West-Indiën gingen Sy noch verder, want in een Artyckel van 't selve Verdragh, moesten wy haer Suriname restaureren, en by verdere Artyckelen in 't selve Verbondt waren Sy gehouden Onse Onderdanen in die Colonie liberteyt te geven, om haer selven en goederen te transporteren in eenige andere van Onse Plantagiën. Achtervolgen van dit Verdragh gaven wy haer die plaets over, niet tegenstaende hielden Sy al ons Volck daer en hielden den Majoor Banister gevangen, omdat hy versocht te transporteren volgens de Artyckelen. 
3. Onze Ambassadeur klagende over dit ongelyck, verkreegh na twee Jaren sollicitatiën, een ordre tot naerkominge van die Artyckelen, maer als wy Commissarisen en twee Scheepen derwaerts sonden om ons Volck af te halen, de Hollanders (volgens haer voorgaende practycke in die saeck van Pouleron, boven de veertigh Jaren na den anderen) sonden heymelyck ordre contradicerende, die Sy Ons openlyck hadden toegeëyent, soo dat het effect van onse Comissarisen haer reyse derwaerts alleenlyk was van daer te brengen eenige weynige van onse armste onderdanen, ende gebeden ende smekingen van de considerabelste en ryckste, om verlost te worden uyt die slavernye. Naer dit maeckte Wy onse klachte in Augusti laestleden door Brieven aen de Staten-Generael waer in wy versochten, dat ordre gegeven mocht worden aen haer Gouverneurs aldaar, tot observantie van de voorsz. Artykelen. Dan tot dese tegenwoordige tyt hebben wy niet een woort in antwoort of satisfactie konnen bekomen".

\section{BiJLAGE III}

blz. 13.

Consideratien over den Tegenwoordigen Toestant van het Vereenigde Nederland, Gestelt door een

Liefhebber van 't Vaderland, Tot encouragement van sijne Landsgenooten, in desen bekommerlijken Tijd, Gedrukt in 't Jaar 1672.

Aangaande het werck van Suriname ('t geen het tweede gepretendeerde grief is in het voorz. Manifest) soo is voor eerst dienthalven seer remercabel, dat het voorschreven werck den Koningh ganschelijck niet en concerneert, maar alleen by hem opgevat is, om te strecken voor een matery van querellen: 't welck op dat de Leser soo veel te bequamer soude konnen begrijpen, gelieve de selve te weten, dat de voorschreve Colonie van Suriname in Martio van den Jare 1667, door eenen Abraham Crijnsen van Zeelandt met de Wapenen van den Staat sijnde bemachtight, en op die wyse onder seeckere Capitulatie ghebracht, onder des selfs Subjectie, bij den Engelschen na de Maandt van Mey daar-aanvolgende, is hernomen, doch dat de selve in krachte van het seste Art. van het Tractaat van Breda, medebrengende dat alle Landen, Steden, Sterckten ende Colonien, gheduurende den Oorlogh by een van de strydende Partyen van den anderen geoccupeert; en na den tienden Oude, en twintighsten May Nieuwe-stijl 1667, hernomen, aan den eersten Nemer souden moeten werden gevestitueert, wederom is ghestelt in den Macht van den Staat.

$\mathrm{Na}$ de selve restitutie is by den Koningh van Engelandt geklaagt, dat aan de Ingesetenen van Suriname niet en wierde gepresteert het effect van de Capitulatie met den voornoemden Crijnsen gemaackt, voor soo veel als de Ingesetenen van de selve Colonie (soo men voor-gaf) de permissie gheweygert soude zijn gheweest om met hare Persoonen en transportabele Effecten elders te vertrecken.

Wat recht is nu de Koningh van Engelandt oyt gebooren geweest om met eenige reden te konnen vorderen de voldoeninge van de Capitulatie, 
ghemaackt met de Ingesetenen van de voorschreve Colonie, die door het recht van den Oorlogh zijn geworden Subjecten van den Staat?

Wat raackt de voorsz. Capitulatie den Koningh van Engelandt meer als den Koningh van Spanjen: Zijn de Ingesetenen van Suriname oock na de Veroveringe van de selve Plaats, uyt kracht van de Capitulatie, gebleven Subjecten van den Koningh van Engelandt? Heeft yemandt oyt gehoort, dat, door Capitulatie, het Jus Imperii, en het oude Recht van den eersten Heer wordt gecontinueert over die geenen, die door de Waapenen worden geconquesteert, alleen omdat sy capituleren, en voor de overgifte conditien maken.

't Is immers notoir en buyten alle controversie, dat de Overwinninge is een wettigen Titul die de Plaatsen en goederen van eygenaar doet veranderen, en de Ingesetenen van Souverain; welk recht by het derde Art. van het Bredasche Tractaat specialijck is bevestight, waar by geconvenieert is, dat yeder met een volkomen recht van heerschappye, eigendom, en besittinge soude blijven behouden alle Landen, Eylanden, Steden, Colonien, en andere Plaatsen, geduurenden Oorlogh by hem geoccupeert en verovert.

Wel is waar, dat door de Capitulatie het recht van de absoluyte dispositie van den Overwinnaar wordt besnoeyt: maar dat de selve soude conserveren het ghebiedt van den voorigen Heer, over de capitulerende Ingesetenen, kan met geen gesonde reden worden over een ghebracht:

Is het den Koning van Spanje oit in gedachten gekomen, dat de Ingesetenen van Maastricht, den Bosch, en Breda, die met de Steden door het recht van de Wapenen, onder Capitulatie over gegaan zijn aan haar Hoog: Mog̃ : door de Câpitulatie souden gebleven zijn sijne Onderdanen ? Of pretendeert de Koningh van Engelandt het voorsz. recht uit de Natie en geboorte ten respecte van de Engelsche Coloniers, als of de selve na de Overwinninghe sijn Onderdanen waren ghebleven? Wie sal seggen dat de gheboorte en taal sulcke effecten souden konnen produceren, strijdigh met de gerecipeerde en by alle Volckeren aangenomen effecten van den Oorlogh, waar door de overwonnene aan den Overwinnaar worden gesubjecteert sonder consideratie van gheboorte of taal.

Zijn dan d'Ingesetenen van Suriname, niet tegenstaande de voorsz. Capitulatie gheworden Subjecten van den Staat, en heeft den Koningh van Engelandt het imperium over haar door het recht van den Oorlogh verlooren, zulcks dat de selve na de Overwinninghe sijne Onderdanen en sijn Volck (soo hij in het voorsz. Manifest haar noemt) niet en zijn gebleven, waar van daan komt het recht om te klagen, dat wy de Ingesetenen van Suriname als sijne Onderdanen niet en hebben doen erlangen het effect van de voorschreve Capitulatie? Is het niet buyten contestatie en alle bedenkinghe, dat de voorsz. Ingesetenen haar daarover aan desen Staat hadden moeten addresseren, ende niet aan den Koning van Engelandt! als aan haren wettigen Souverain; sonder dat daartegens eenige consideratie meriteert, 't geen voor desen by ofte van wegen den Koningh van Engelandt, tegens de substantie, van het voor-heen geduceerde, in de sake van Suriname is geobjecteert, en niet duysterlijk wederom wordt aan-geroert in het voorschreve Manifest, te weten, dat de woorden, in dier voegen soo als by de selve op den tienden Oude, en den twintighsten Mey Nieuwe styl hadde geoccupeert, in het eynde van het derde Art. van het Bredaasche Tractaat influerende, de macht van hare Hog: Mog: in faveur van den Koningh en tot conservatie van des selfs oude Heerschappy over de Ingesetenen van 
Suriname souden bepalen: gemerkt uit de connexiteyt, en de waarachtige sin, van het gemelde Art. lichtelijck is te begrijpen, dat de voorschreve woorden, in voegen, niet en limiteren de heerschappye over het gene genomen is, maar alleen de uytstreckinge van de possessie: sulks dat de meininge niet en is geweest om met die woorden uit te drucken, dat yeder het geoccupeerde niet anders soude blijven behouden als met soodanigen besnoeyinge van heerschappy, als hy het selve by Capitulatie hadde verkregen, maar alleen dat het recht van den Overwinnaar niet wijder, dat is over geen meerder Landt, soude worden geëxtendeert, als volgens de occupatie van den tienden Oude, en den twintighsten Mey Nieuwe styl, behalven noch, dat uit de voorsz. woorden, indien daarmede al op de bepalinge van de heerschappye, en sulks op de voorsz. Capitulatie soude mogen wesen gereflecteert (des ganschelijk neen) ten hooghsten niet anders soude konnen worden getrokken, als dat men het gene, waardoor het imperium van den Overwinnaar soude mogen besnoeyt zijn, heeft willen laten in sijn waarde, en dat door die genen die uit de selve besnoeyinge eenig recht soude mogen hebben geacquireert, dat is in cas subject voor de Ingesetenen die eenige Capitulatie souden mogen heben gemaakt, ende geensins voor der selver Heer.

Welke defensie of wel in der daet van die kracht is geweest, dat men daar mede den Koningh van Engelandt hadde konnen afsetten, so hebben echter haar Ho: Mog: uyt een loutere estime van de selve Majesteit, in wiens vrientschap sy haar altyt ten hoogste hebben geinteresseert, met den Heere Ambassadeur Temple geconcerteert over de executie van het 15. en 19. Articulen van de voorsz. capitulatie, betreffende het vertreck van de ingesetenen van de voorsz. Colonie met hare goederen, en hebben vervolgens aan den Commandeur van de voorsz. Colonie de volvoeringe van het geconvenieerde by expresse missive aenbevolen, sonder dat sy deselve last by secrete ordres (als in het voorsz. Manifest calumnieuselyk wort gesegt) oyt hebben gecontramandeert, gelyck ook voor desen noyt en is geschiet in de sake van Pouleron.

Wy souden alhier de goede trouwe omtrent de volvoeringe van de voorsz last in Suriname, by den Commandeur gepleeght parlemenu, konnen aanwysen, en te gelijk de wreveligheyt van de Commissarisen van den Koningh van Engelandt omtrent de selve saken, maar wy sullen ons (om in dit kort geschrift niet al te lang te sijn) daer van, met permissie van den leser, dispenseren, en de voldoeninge van des selfs curieusheyt uyt stellen tot den tyd, dat het contramanifest van den Staat het licht sal sien, 't geen ongetwyfelt een omstandigh bericht van de sake, met bijvoeginge van documenten en bewysen sal behelsen.

(Het pamphlet, waaraan het bovenstaande ontleend is en waarvan ook een Duitsche vertaling bestaat, is in het bezit van Dr. H. D. Benjamins, die het welwillend te mijner beschikking stelde. Het pamphlet is door Knuttel genoemd onder no. 10008. Daar worden verscheidene uitgaven beschreven, alle, ook de Duitsche vertaling, uit het jaar 1672.

Het hier gebruikte exemplaar komt met het eerste door Knuttel beschreven pamphlet geheel overeen met dit kleine verschil dat bij het exemplaar bij Knuttel op het titelblad „Toestand” staat, op het exemplaar van Dr. Benjamins „Toestant”. 